\title{
The Impact of Foreign Direct Investment on Income Inequality in Vietnam
}

\author{
Quoc Hoi Le ${ }^{1, *}$, Quynh Anh Do ${ }^{1}$, Hong Chuong Pham ${ }^{2}$ and Thanh Duong Nguyen ${ }^{3}$ \\ 1 Faculty of Economics, National Economics University, Hanoi 100000, Vietnam; doquynhanh1510@gmail.com \\ 2 Faculty of Tourism and Hospitality, National Economics University, Hanoi 100000, Vietnam; \\ chuongph@neu.edu.vn \\ 3 School of Banking and Finance, National Economics University, Hanoi 100000, Vietnam; \\ thanhduong208@gmail.com \\ * Correspondence: hoilq@neu.edu.vn
}

check for

updates

Citation: Le, Quoc Hoi, Quynh Anh Do, Hong Chuong Pham, and Thanh Duong Nguyen. 2021. The Impact of Foreign Direct Investment on Income Inequality in Vietnam. Economies 9: 27. https://doi.org/10.3390/ economies 9010027

Received: 17 November 2020 Accepted: 19 February 2021 Published: 1 March 2021

Publisher's Note: MDPI stays neutral with regard to jurisdictional claims in published maps and institutional affiliations.

Copyright: (C) 2021 by the authors. Licensee MDPI, Basel, Switzerland. This article is an open access article distributed under the terms and conditions of the Creative Commons Attribution (CC BY) license (https:/ / creativecommons.org/licenses/by/ $4.0 /)$.

\begin{abstract}
Foreign direct investments (FDI) is an important determinant of economic growth. FDI does not only contribute to the growth and economic development but also affects income through contributing to economic development and the impact on employment and salary structure of developing countries. The aim of this paper is to analyze the impact of FDI on income inequality in Vietnam. This study is the first attempt to examine the impact of FDI on income inequality under the constraints of the institution and education levels. To address the potential endogeneity problem, this study adopts Genernalized Method of Moment (GMM) model to conduct the estimation. A two-step GMM model with robust standard errors is used in the study. Empirical results show that FDI tends to increase income inequality in Vietnam and the existence of a non-linearity relationship between FDI and income inequality is also validated. Moreover, the study finds that the effects of FDI on income inequality are different depending on the level of education and institutions of the host provinces in Vietnam. The results of this study imply that, in order to ensure sustainable development, Vietnam's policies should focus on improving the quality of economic governance and the administrative reform efforts of the government of the provinces and cities. Besides, policies should focus on increasing investment in public education and improving human capital, which not only can reduce income inequality but also can attract more FDI inflows.
\end{abstract}

Keywords: foreign direct investment; income inequality; Vietnam; GMM

JEL Classification: F43; F63

\section{Introduction}

In recent decades, there have been many studies on the effects of foreign direct investment (FDI) on socio-economic variables. Studies are concerned with the effects of FDI on economic efficiency, productivity, and growth at both the micro and macro levels (e.g., Javorcik 2004; Kugler 2006). Most studies have assessed that FDI has a positive impact on the host country's economy, especially in developing countries, but its effects on social equity, including income inequality are not consistent.

The impact of FDI on income inequality is a concern for many reasons. First, income inequality has a negative effect on economic growth (Cingano 2014). Second, the rise in income inequality may hamper the progress of poverty reduction. Finally, people who are concerned with relative income often have a desire to live in an equal society (Figini and Görg 2011; Sylwester 2005). Therefore, if FDI increases income inequality, its positive effects on economic growth will be replaced by a lower rate of growth as well as other socioeconomic negative effects. This is a big concern for developing countries, which are heavily reliant on FDI. In these countries, social stability plays a key role in economic development. 
In Vietnam, inequality in income distribution represented by the Gini coefficient ranged from 0.42 to 0.44 during the period 2010-2018. However, the Gini coefficient tends to increase in less developed regions, especially in the Central Highlands with the highest Gini coefficient in Vietnam in 2016. Notably, although the Gini coefficient is not high, the absolute income inequality is rising. The income per capita of the top $20 \%$ of households in 2010 increased from 9.2 times the average income per capita of the $20 \%$ lowest income households in 2010 to 9.8 times in 2016 (Hung 2019).

Some studies show that the FDI sector has positive effects on income inequality reduction in Vietnam (Nam 2016; Hue 2016; Le 2019), while other studies have found the opposite results (Huyen 2012; Nga and Tri 2017). However, the number of studies on the relationship between FDI and income inequality in Vietnam is limited. In addition, studies have not yet shown the impact of FDI on income inequality under the constraints of the institution and education levels. Therefore, this article will focus on addressing this research gap.

In this study, we focus on analyzing the impact of FDI on income inequality in Vietnam. First, we present a theoretical model to describe the impact of FDI on income inequality. Then, we use system Genernalized Method of Moment (GMM) estimation method with panel data for 63 provinces during the period 2012-2018 to analyze the impact of FDI on income inequality under linear and non-linearity relationships. In addition, we investigate the relationship between FDI and income inequality under the moderating effects of education and institutions.

In this study, the author introduces a new aspect that the quality of the institution has a regulatory effect on the relationship between FDI and income inequality. This aspect is relevant to research in developing countries whose institutions differ significantly from those of developed countries and influence the way multinational companies operate and interact with localities (Cantwell et al. 2010; Peng et al. 2008). Institutions are not a direct factor affecting the income of workers, but act as a regulatory factor, having a great influence on the efficiency of production and business of enterprises, which thereby affects the income of workers. A locality with good institutions will benefit businesses choosing that locality. If the locality has an open and low-cost market entry procedure to attract investment, businesses will save significantly in the amount of costs spent on setting up a new business, then they will have more capital to invest in factory construction, research and development, and labor training, leading to higher operational efficiency and improved wages. In addition, for business operations, informal fees are also seen as a major obstacle. The author argues that a good institution with open market entry procedures, an environment of fair competition, low informal costs, good legal institutions, and administrative reform efforts of local governments can positively affect the impact of FDI on income inequality.

Besides, the authors also analyze the relationship between FDI and income inequality under the regulatory impact of human capital. Individuals whose education is based on their own competencies, demographic characteristics and other characteristics that are not related to the emergence of FDI are skilled workers. Inequality will increase as the demand for knowledge and skills increases, leading to higher demand for skilled labor. This view is expressed in the study of Barro (2000) whereby the authors argue that the higher the level of education in the population, the lower the income inequality. Since FDI does not affect (increase or decrease) the level of education of this group, but the education level does affect their income, it is, therefore, a regulating factor. Te Velde and Xenogiani (2007) have shown that FDI only enhances skills in countries with relatively good initial human capital levels. Through training and improving the skills of workers, income inequality will also be reduced. In addition, human capital determines whether a domestic company benefits from technology transfer through FDI or not. Host countries need to have an adequate level of human capital in order to benefit from FDI. Therefore, the study of the relationship between FDI and income inequality under the impact of human capital is very important. 
This article is structured into five parts: (i) Introduction; (ii) Research overview; (iii) Research methodology; (iv) Results, and; (v) Conclusion.

\section{FDI and Income Inequality: Theory and Literature}

\subsection{Theoretical Framework}

The effects of FDI on income inequality so far have only been mentioned properly in the research paper. However, in general, from the theoretical point of view, the impact of FDI on income inequality has been studied based on two views, that is, an endogenousgrowth model of the nonlinear hypothesis, and the North-South model on the linear hypothesis. These are also research projects that set up the initial scientific basis for the implementation of empirical studies in countries and groups of countries around the world.

The theory that supports the nonlinear hypothesis explaining the effect of FDI on income inequality is represented by the endogenous growth model of Aghion and Howitt (2009). According to this theory, a change in technology causes the income gap between unskilled and skilled workers. Based on the economic model, the authors suggest that there are two stages of development in transferring new technology from multinational enterprises (MNEs) to the host country. In the first phase, since domestic companies are in the process of learning from the MNEs to apply new technology, domestic firms need a portion of the skilled labor force to carry out the research required to implement the new technology. In this process, the budget invested in technology innovation is relatively small as old technology is mainly used by domestic firms. As a result, the demand for skilled workers remains low, leading to similar incomes for skilled and unskilled workers. In the second stage of development, domestic firms successfully implement the model of using new technology to produce products. In the process of implementation, businesses using new technology only need skilled labor for production. As a result, the demand for skilled labor increases sharply, which affects the labor market segment. The requirement of skills in the early stages leads to an increase in the demand for new skills. This results in an increase in income inequality during this period. Then, the income inequality decreases as the provision of the necessary skills improve and the companies complete the transition to a new technology model. In addition, low-skilled workers try to gain more qualifications to become skilled workers, so they can join the middle-income class, which leads to the previously reduced inequality distinctions.

Unlike the endogenous growth theory, the North-South model theory shows that FDI increases income inequality. This model was developed by Feenstra and Hanson in 1997 and assumes that the countries in the north are developed countries with an abundant skilled workforce and the countries in the south are underdeveloped countries where labor is mainly unskilled. Subsequently, firms in the northern countries, which include mainly skilled workers, would hire firms in the southern countries, where unskilled workers were concentrated to produce intermediate inputs. Feenstra and Hanson (1997) provide a model of production globalization, explaining that an increase in the capital of the southern countries relative to the northern ones can increase the relative wages of skilled labor in both regions. The reason is that the availability and cheapness of labor in underdeveloped countries are factors attracting FDI from developed countries where labor is considered as both scarce and expensive. Therefore, MNEs will reduce costs by using the labor-intensive factor in the production process. However, from the northern countries' perspective, the production jobs transferred to the southern countries are simple activities, but those jobs in the southern countries can be considered as highly skilled activities. This implies that some activities can be considered as low-skills in one country but as high-skills in other countries. Thus, this type of FDI may increase demand and wages for skilled workers not only in developed countries but also in less developed countries. Some empirical studies (Aitken and Harrison 1999; Feenstra and Hanson 1997; Lipsey and Sjöholm 2004) support the hypothesis derived from a resource-based North-South model. Therefore, FDI has a negative effect on inequality by increasing demand and wages for skilled workers in poorer host countries 
Both the linear and nonlinear schools of theory determine and differentiate the effects of FDI on income inequality in developed and developing countries. According to these views, it cannot be concluded theoretically that FDI increases or decreases income inequality for host countries. Although the endogenous growth model theory outlines the negative effects of FDI in the early stages of development, it stills shows that in later stages of development, FDI invested into many sectors ultimately improves income inequality. In addition, the North-South model theory concludes that FDI is an obvious factor in deteriorating income inequality.

The heterogeneity of theoretical models leads to the need for more empirical research to determine the effect of FDI on inequality. More importantly, it prompts the researcher to re-test the accuracy of various theoretical predictions based on the economic development level of the host country.

\subsection{Literature Review}

It can be divided into four empirical research groups on the relationship between FDI and income inequality as follows:

\subsubsection{FDI Has No Impact on Income Inequality}

Goldberg and Klein (2005) argued that FDI generally has no clear effects on the income distribution of the host country. If any effect exists, it tends to reduce inequality instead of aggravating inequality. Recently, in the era of globalization, the role of FDI in economic growth and income distribution has become an increasingly important topic. The research results of Milanovic (2002) are largely consistent with Goldberg and Klein's argument. Specifically, this study, which uses panel data on 88 countries for the period 1985-1998, concludes that FDI has no effect on income distribution.

Aside from Milanovic (2002), there are many other later studies that have found similar results. In the study on the relationship between FDI and income inequality, Hemmer et al. (2005) did not find any evidence that FDI affects inequality at the general level or has a significant impact on income distribution. Using data on 29 developing countries for the period 1970-1989, Sylwester (2005) also found no evidence of the distributional effect of FDI on income inequality. Faustino and Vali (2011) analyzed the correlation between income inequality in OECD countries and economic globalization by measuring trade openness and FDI over the period 1995-2007. They found that while trade openness reduces income inequality, the impact of FDI on inequality is relatively slight.

Franco and Gerussi (2013) conducted a study to analyze the effect of FDI on income inequality in a group of 17 transition countries. The authors did not find a direct link between FDI and income inequality but emphasized that the type of FDI could have a negative impact on income inequality.

\subsubsection{FDI Has the Effect of Reducing Income Inequality}

Jensen and Rosas (2007) show that FDI in Mexico between 1990 and 2000 led to a decrease in income inequality at the state level. Bhandari (2007) evaluated FDI in the United States and argued that it had a beneficial distributional effect, but with significant variation across regions and periods. Herzer and Nunnenkamp (2011) used data of 10 European countries between 1980 and 2000 and found that, initially, FDI resulted in an increase in income inequality in the short run, but in the long run, FDI made no direct or indirect contribution to income inequality reduction in those countries. A similar conclusion was made by Chintrakarn et al. (2012) which suggested that FDI in the United States decreased income inequality but the effect was again inconsistent across states. Mugeni (2015) using a panel data set of 153 developed and developing countries between 1995 and 2010 also show that FDI, coupled with a degree of democracy, reduces income inequality. Furthermore, the results show that foreign investment flows reduce income inequality in countries with higher levels of democracy. 


\subsubsection{FDI Has the Effect of Increasing Income Inequality}

In an analysis of panel data across 88 countries over the period 1967-1994, Alderson and Nielsen (1999) found a positive relationship between FDI and income inequality. Beer and Boswell (2002) continued to use panel data of 65 countries between 1980 and 1995, showing that dependence on FDI may lead to a problem for countries that are committed to income inequality. The authors also pointed out the important role of education in improving human resources, contributing to a more even distribution of income without affecting growth negatively.

The negative effects of FDI are also found in the study of Reuveny and Li (2003) using data from 69 countries for the period 1960-1996. Choi (2006), who conducted research based on 119 countries over the period 1993-2002, reached a similar conclusion that an increase in FDI as a percentage of gross domestic product (GDP) is associated with higher income inequality in those countries. In a panel study of 119 developing countries between 19701999, Basu and Guariglia (2007) found that FDI promotes growth but also increases income inequality in host countries. In Tsai (1995) study using multinational datasets from 33 developing countries, the research results show that FDI increases inequality in some Asian countries. Gopinath and Chen (2010) use a sample of 11 developing countries showing that FDI inflows widen the wage gap between the skilled and unskilled labor group.

Several studies across a single country also show that FDI leads to higher inequality. Jin (2009) examined the effect of FDI on income inequality in China, using panel data of 25 provinces over the period 1990-2006. It was concluded that FDI aggravates inequality in urban areas but has little or negligible impact on inequality between urban and rural areas. The author argued that because the structure of FDI in China is mainly concentrated in coastal areas where income inequality is much lower than inland regions, it attract less FDI. Taylor and Driffield (2005) explained that this increase in inequality is due to the fact that FDI firms often require higher skills than domestic firms, leading to wage gaps for workers in different sectors. A study conducted by Girma and Görg (2007) in the UK found that multinationals in the UK pay higher wages than domestic firms, leading to a large income gap among workers. Skilled and unskilled employment affects the level of income inequality in this country. These studies all suggest that foreign firms have different demands of labor compared to domestic firms.

Other studies have also shown a positive correlation between FDI and inequality in the wages of skilled and unskilled workers (Aitken and Harrison 1999; Te Velde 2003). Feenstra and Hanson (1997) argued that capital flows from developed countries to developing countries through the process of outsourcing, implying that developed countries use mainly unskilled labor. By using Mexican data for the period 1975-1988, Feenstra and Hanson (1997) find that the increase in income of skilled labor is mainly explained by FDI.

In considering the impact of international policies, it should be noted that FDI inflows into Vietnam have been increased by a large number of bilateral investment treaties (BITs) (Vinh et al. 2014). By using the methodology of Chaisse and Bellak (2015), Vinh et al. (2014) built up the BIT index for Vietnam. The result was that signing the BIT helped Vietnam to attract more FDI and more favorable BITs lead to further FDI inflows into the country. According to Bodea and Ye (2017), BITs increase income inequality in developing countries. BITs not only are able to deter capital-hosting governments from implementing redistributive policies but also can lock-in initial investment attractive policies in the fields of taxes, welfare spending, and labor standards and constrain future improvements in those policy fields, resulting in decreasing government revenue/spending and worsening labor practice. These findings implied that developing countries need more efforts to balance the protection of foreign investors with the goal of domestic sustainable social and environmental development in the BITs language, for instance, the main text of BITs should incorporate labor-related and social development clauses. Besides, BITs favor foreign over domestic investors; therefore, welfare-maximizing investment policies should avoid an allocation bias between domestic and foreign investors (Bellak 2015). 


\subsubsection{FDI Has a Nonlinear Relationship with Income Inequality}

In a study of a large sample of more than 100 developed and developing countries during 1980-2002, Figini and Görg (2011) also found a nonlinear effect of FDI on income inequality in developing countries. Furthermore, when examining the effect of FDI on inequality in OECD and non-OECD developing countries separately, the study found a clear difference between these two groups of countries. For the group of non-OECD developing countries, the study found that the effect of FDI on income inequality is nonlinear in an inverted U-shape. Specifically, the inflow of FDI initially increased income inequality, but then, the increase in FDI inflows reduced the level of inequality in these countries. However, no evidence was found in developed countries. In the study of Blonigen and Slaughter (2001) on states in the US, the nonlinear effect of FDI on income inequality between the skilled and unskilled workers was also not statistically significant.

Thus, studies have shown the existence of a correlation between FDI and income inequality. However, neither theoretical nor empirical research has come to a consensus on whether FDI increases or decreases income inequality. This depends on the country/region studied, the representative variable of the income inequality used, the estimated model and the dependent variables, the control variables included in the model, the method used by the model, and the research period. The difference in research results depends on the capital absorption capacity and development strategy of each country receiving foreign investment. Therefore, there is a need for further study on the relationship between FDI and income inequality in specific contexts.

\section{The Vietnamese Case}

Vietnam has been attracting foreign investment since 1988 since the promulgation of the Law on Foreign Investment of Vietnam in 1987. The 30-year period from 1988 to 2018 is long enough to properly assess the importance of foreign direct investment (FDI) to the economy and society of Vietnam. Because Vietnam has many advantages to attract FDI such as abundant human resources, potential markets, stable politics, and abundant and diversified natural resources, the FDI sector has developed very rapidly, contributing more and more to the economic development of Vietnam.

During the period from 2012 to 2018, the total number of licensed FDI projects was 15,281 , the total registered stock was 185.097 billion USD, and the total implemented stock was 100.904 billion USD in Vietnam. FDI has risen substantially in Vietnam during the period of 2012-2018, as Figure 1 shows. Currently, there are 135 countries and territories investing in Vietnam. South Korea is the biggest partner, followed by Japan, Singapore, and Taiwan. Besides economic benefits, FDI also has a positive impact on exchanges between different cultures through the process of mutually beneficial cooperation between Vietnamese people and many ethnic groups around the world.

Like other countries around the world, in Vietnam, inequality is still a major challenge to economic and human development goals. To assess inequality, there are many measures used in practice, of which the Gini coefficient is most commonly used. Figure 1 shows that the income inequality of Vietnam in the period of 2012-2018 was unstable and fluctuated from 0.424 in 2012 to 0.436 in 2016, then decreased to 0.422 in 2018. Although the level of variation in the Gini coefficient is not high (0.422 to 0.436$)$, it also shows that the income of the employee has changed over the years. 


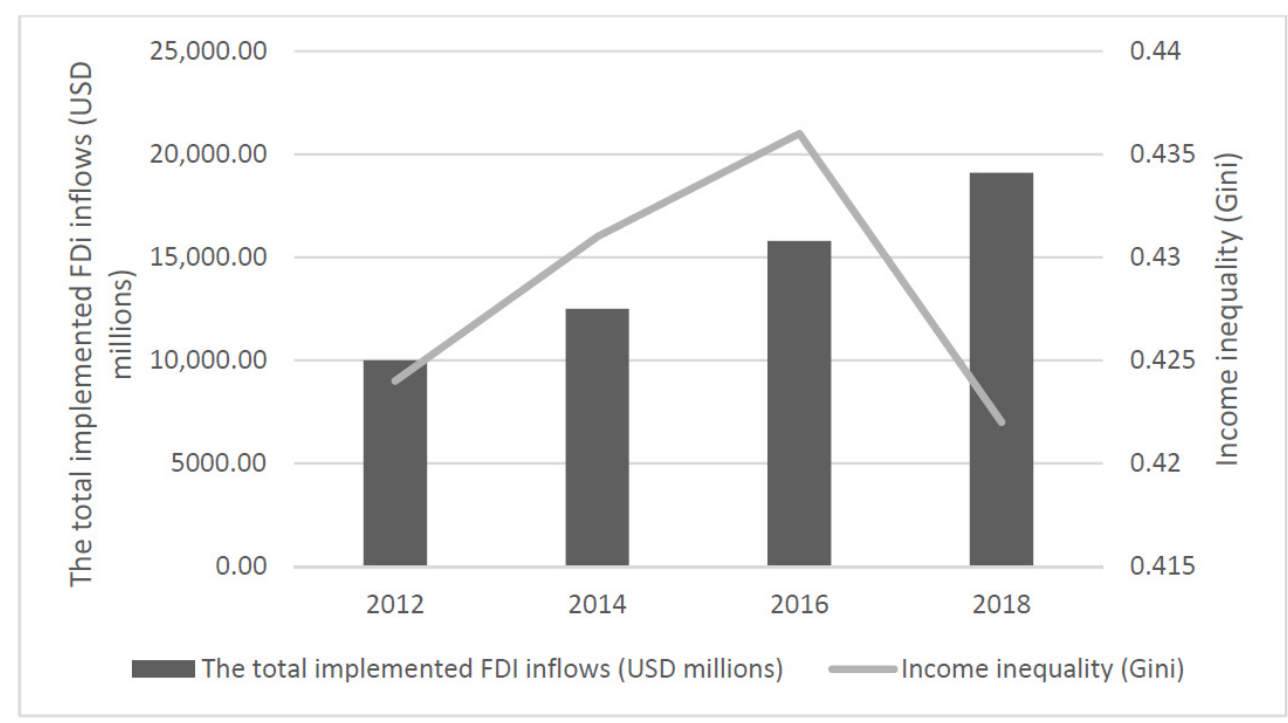

Figure 1. Foreign direct investment (FDI) and income inequality in Vietnam (2012-2018). Source: General Statistics Office of Vietnam.

In terms of the income of workers in FDI enterprises, it has created a rich-poor gap between industries in the FDI sector and between FDI and other regions. Figure 2 shows that the average salary of FDI firms is higher than that of domestic firms, but there are differences between periods. Specifically, the ratio of the average salary of the FDI sector to domestic firms increased in the period 2012-2014, then decreased in the period 2014-2018 (Figure 2).

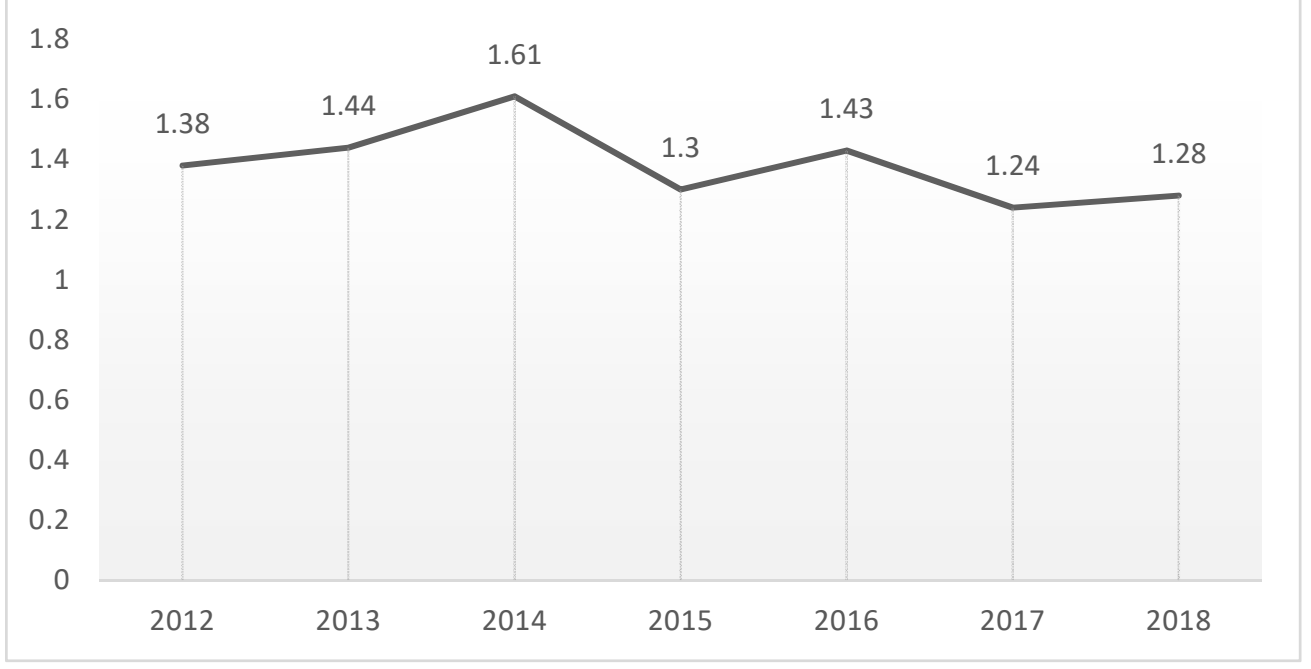

Figure 2. The ratio of FDI enterprises'wages to domestic firms' wages. Source: Authors' calculations from Enterprise Survey data.

An analysis of Vietnam's data also shows that FDI can cause inequality between regions, as the average wage income of the regions with the largest FDI attraction, the Red River Delta and the Southeast is also significantly higher than the rest of the region. Regional income inequality not only shows differences in wages among FDI firms across regions but also in wages of domestic firms (Figure 3). 


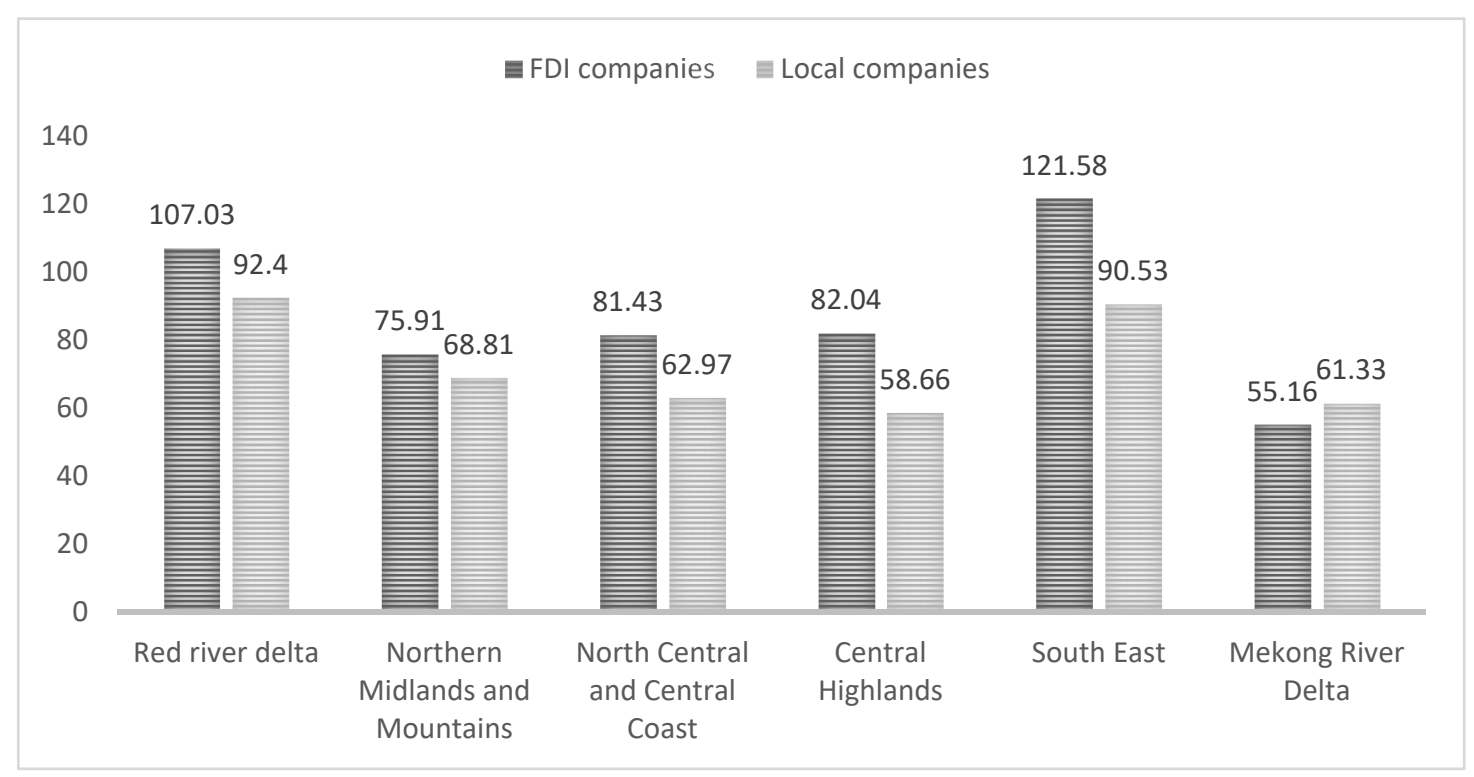

Figure 3. Average salary of Vietnamese employees in 2018 (million VND/person at current price). Source: Authors' calculations from Enterprise Survey data.

Thus, a comparative analysis of wage income in FDI and domestic firms also shows that foreign direct investment in Vietnam tends to increase income inequality. This phenomenon is not only limited to the local scope but also manifests clearly among economic regions.

\section{Econometric Analysis}

\subsection{Empirical Model}

Based on the theoretical model of Aghion and Howitt (2009) and the first general equilibrium trade model by Feenstra and Hanson (1997), the authors estimate the impact of FDI on income inequality in Vietnam by using the following empirical model:

$$
\operatorname{GINI}_{i t}=\beta_{0}+\beta_{1} \cdot F D I_{i, t}+\beta_{j} \cdot X_{i, t}+\varepsilon_{i t}
$$

In this model, $i$ and $t$ denote province $i$ and year $t$ respectively. Gini coefficient is a measure of income inequality for province $i$ in period $t$; the variable FDI is the ratio of the total implemented FDI inflows to GDP at constant 2010 prices in province $i$ year $t$.

In this study, the Gini coefficient is calculated from the Vietnam Household Living Standards Survey conducted by the General Statistics Office (GSO) every 2 years. We calculated the Gini coefficient based on the income from the employee's salary. The calculation of wage income inequality will show more clearly the impact of FDI on income inequality in Vietnam.

Theoretically, this model contains a set of control variables that can affect income inequality or FDI because ignoring them can lead to improper estimates and could have an effect on estimating the impact of FDI on income inequality. According to the theory of FDI and income inequality, control variables are given in the equation: trade openness, economic development, human capital, unemployment rate, inflation, and institutions. In this study, only macroeconomic factors influencing the Gini coefficient with an emphasis on FDI are taken into account.

The variable, Openness, is taken from the work of Heckscher et al. (1991), who argued that trade increasing in countries with a majority of unskilled workers reduces inequality. On the other hand, inequality will increase in countries where skilled labor dominates (Feenstra and Hanson 1997). Based on the specific factors of an international trade model, it can be concluded that trade liberalization will force countries to focus on the production in which they have a comparative advantage. As a result, trade liberalization will bring benefits to the exporting sector and hamper the importing sector. Since Vietnam 
has a strong comparative advantage in labor-intensive manufacturing industries and a comparative disadvantage in agricultural production, manufacturing will be influenced positively by trade liberalization while the impact on agriculture is negative. Consequently, trade liberalization will tend to widen income disparity, and the sign of the coefficient of the variable of TRADE/GDP is expected to be positive. In this study, Openness is total trade (import plus export) over GDP of the province in year $t$, reflecting the trade openness from a macro perspective (\% of total exports + imports/GDP). Greater trade openness is expected to create diverse opportunities for all economic sectors, having a strong impact on the overall growth and income of each social group.

The level of economic development will be represented by GDP per capita (Tsai 1995; Figini and Görg 2011). The expected indication of GDP per capita is positive or negative. Economic growth leads to an increase in a country's income inequality if everyone cannot enjoy its results equally. On the other hand, economic growth can lead to a reduction in income inequality if labor absorbs economic growth and policies related to income distribution are more efficient. The variable PGDP is calculated by the GDP per capita of province $i$ in year $t$ at constant 2010 prices (VND million/person).

Human capital is the variable included to control the supply side of the labor market because of changes in the supply and demand of skilled labor. When the proportion of trained workers is higher, the supply of skilled workers is correspondingly high. Figini and Görg (2011) suggested that an increase in the supply of skilled labor will reduce wage inequality. Thus, a higher level of education is likely to reduce income inequality. The variable $\mathrm{HC}$ represents the level of human capital, represented by the proportion of trained workers in province $i$ in the year $t$.

The unemployment level is used in the model because it can have a profound effect on income inequality due to the ability to negotiate wages (Te Velde 2003). Furthermore, the unemployment rate is closely linked to economic liberalization and development processes and thus affects income distribution (Dix-Carneiro 2014). The UNEM variable represents the unemployment rate aged 15 years and over in the population of province $i$ in the year $t$.

The fifth control variable-inflation has a greater impact on the poor because their real assets and income (at constant price) are dramatically reduced. As a result, high inflation often increases the income gap. Inflation is measured by the consumer price index (CPI) of province $i$ in the year $t$.

In this article, the components of the Provincial Competitiveness Index in Vietnam represent the institutions. The PCI is used to assess the business environment, the quality of economic governance, and the administrative reform efforts of the government of the provinces and cities in Vietnam, thereby promoting the development of the non-state economic sector. The PCI includes 10 indexes, reflecting the areas of economic governance that have impacts on the development of the private sector, including: market entry costs; land access and stability in land use; transparency of business environment and business information; unofficial fees; inspection, examination and implementation of administrative regulations and procedures time; competitive environment; the pioneering and dynamism of provincial leaders; business support services; labor training policy, and; dispute resolution procedures. These indicators are calculated on a monthly basis of 100 points and ranked according to the provinces of Vietnam.

Finally, the urbanization variable is measured by the ratio of the urban population to the total population of province $i$ in the year $t$. This is because the fluctuation of the urban population is mainly due to the urbanization process. The explosion of urbanization has caused the rapid increase of the urban population and spurred national or local economic growth, increasing income and living standards. In addition, the process of urbanization also attracts workers from local areas to cities to look for jobs. Therefore, the urbanization process also affects income inequality. 
We also consider the existence of an inverse U-shaped relationship according to the model of Aghion and Howitt by adding the squared variable of the variable FDI, denoted by $F D I^{2}$ (FDIsq) to model (2).

$$
G I N I_{i t}=\beta_{0}+\beta_{1} \cdot F D I_{i, t}+\beta_{2} \cdot F D I s q_{i, t}+\beta_{j} \cdot X_{i, t}+\varepsilon_{i t}
$$

As discussed above, the effect of increasing or narrowing the income inequality of FDI depends on the quality of the local institutions and education level. To examine whether FDI affects income inequality under the constraint of regulation, the interaction variable between FDI and institutions (FDI $\times$ Institutions) and the interaction variable between FDI and education level (FDI $\times$ Human Capital) is added to the model respectively.

$$
\begin{aligned}
& \text { GINI }_{i t}=\beta_{0}+\beta_{1} \cdot F D I_{i, t}+\beta_{2} \cdot F D I_{i, t} \times \text { Institutions }_{i, t}+\beta_{j} \cdot X_{i, t}+\varepsilon_{i t} \\
& \text { GINI }_{i t}=\beta_{0}+\beta_{1} \cdot F D I_{i, t}+\beta_{2} \cdot F D I_{i, t} \times \text { Human Capital } \\
& i, t+\beta_{j} \cdot X_{i, t}+\varepsilon_{i t}
\end{aligned}
$$

In the model (2), (3), (4), besides the variable FDIsq and two interactive variables, the other variables in the model are used similarly to model (1).

\subsection{Data}

This study uses provincial-level panel data containing 63 provinces over the period 2012-2018 in Vietnam. All data in this study are collected from the General Statistics Office of Vietnam. Since the main objective of this paper is to investigate the impact of FDI on income inequality in Vietnam, the dependent variable used in this study is the Gini coefficient. As mentioned above, the sign of the variable of FDI/GDP could be either positive (increasing income inequality) or negative (reducing income inequality), subject to an empirical investigation.

\subsection{Dealing with Endogeneity Issues}

The major concern in the regression is the endogeneity problem. First, FDI is likely to flow into the provinces having better economic growth. Second, some macroeconomic policies may boost economic growth and attract FDI inflows at the same time. In addition, the FDI variable may be correlated with those uncontrolled factors in the regression model. Many time-invariant and time-variant macro- and province-specific factors which are unobserved are concluded to affect provincial economic growth and also to be correlated to FDI inflows into the provinces. Since economic growth has an effect on income inequality, the FDI variable may be endogenous. This problem could bias the estimated impact of FDI on income inequality.

To tackle the potential endogeneity problem, the system GMM model could be applied to conduct the estimation. A two-step system GMM model with robust standard errors is used in our research (Arellano and Bond 1991).

\section{Regression Results and Explanations}

Column 1 in Table 1 reports the estimation results of the direct impacts of FDI on income inequality. The estimation results show that the variable FDI has a positive impact on income inequality and is statistically significant at the 1 percent level. This means that FDI will have a negative effect, increasing income inequality in Vietnam. Column 2 in Table 1 is model (2) with the variable FDIsq (squared of FDI) added significantly at $10 \%$ and is negative. This finding reveals that there exists a non-linearity relationship between FDI and income inequality according to the prediction of Aghion and Howitt (2009). Thus, the empirical results conclude that in the 2012-2018 period, the FDI expansion led to an increase in income inequality, but at a gradual declining rate over time. This result is consistent with Hung (2019) on the existence of an inverse U-shaped relationship between FDI and income inequality in Vietnam.

The fact that FDI initially increases income inequality in Vietnam can be explained for the following reasons. First, according to data from the Vietnam Enterprise Survey, the 
average salary of FDI firms is higher than domestic firms. During the period 2012-2018, the rate of the FDI business sector's wages per domestic corporate wages fluctuated from 1.38 times in 2012 to 1.28 times in 2018, of which the highest point was 1.61 times in 2014 . Second, an analysis of data collected from the Vietnam Enterprise Survey also shows that FDI can cause inequality between regions. When the average wages of regions that attract a large amount of FDI including the Red River Delta and the Southeast regions are also significantly higher than the rest of the regions. Thus, a comparative analysis of wages in FDI and domestic firms also shows that foreign direct investment in Vietnam tends to increase income inequality. This phenomenon that occurs is not only limited to the local scope but also manifests clearly among economic regions.

Table 1. The impacts of FDI on income inequality.

\begin{tabular}{|c|c|c|c|c|}
\hline Independent Variable & Model 1 & Model 2 & Model 3 & Model 4 \\
\hline FDI & $\begin{array}{c}0.0941 * * * \\
(0.034)\end{array}$ & $\begin{array}{c}0.3249 * * \\
(0.158)\end{array}$ & $\begin{array}{c}1.3484 * \\
(0.796)\end{array}$ & $\begin{array}{c}0.5265 * \\
(0.312)\end{array}$ \\
\hline FDIsq & $\begin{array}{l}- \\
-\end{array}$ & $\begin{array}{c}-0.1550 * \\
(0.086)\end{array}$ & - & - \\
\hline $\ln P G D P$ & $\begin{array}{c}0.0329 * * * \\
(0.008)\end{array}$ & $\begin{array}{c}0.0449 * * \\
(0.018)\end{array}$ & $\begin{array}{c}0.0150 \text { ** } \\
(0.007)\end{array}$ & $\begin{array}{c}0.0067 * * \\
(0.010)\end{array}$ \\
\hline Human capital & $\begin{array}{c}-0.0139 * * * \\
(0.003)\end{array}$ & $\begin{array}{c}-0.01422^{* * *} \\
(0.005)\end{array}$ & $\begin{array}{c}-0.0065^{* *} \\
(0.003)\end{array}$ & $\begin{array}{c}-0.0002 \text { * } \\
(0.001)\end{array}$ \\
\hline Openness & $\begin{array}{c}-0.0008 \\
(0.001)\end{array}$ & $\begin{array}{c}-0.0007 \\
(0.001)\end{array}$ & $\begin{array}{c}-0.0003 \\
(0.001)\end{array}$ & $\begin{array}{c}-0.0019 \\
(0.002)\end{array}$ \\
\hline Inflation & $\begin{array}{l}0.0004 \\
(0.001)\end{array}$ & $\begin{array}{c}-0.0012 \\
(0.002)\end{array}$ & $\begin{array}{l}0.0017 \\
(0.001)\end{array}$ & $\begin{array}{l}0.0028 \\
(0.001)\end{array}$ \\
\hline Unemployment & $\begin{array}{c}-0.0072 \\
(0.005)\end{array}$ & $\begin{array}{l}0.0063 \\
(0.011)\end{array}$ & $\begin{array}{c}-0.0016 \\
(0.005)\end{array}$ & $\begin{array}{l}0.0002 \\
(0.000)\end{array}$ \\
\hline Urbanization & $\begin{array}{c}0.0030^{* * *} \\
(0.001)\end{array}$ & $\begin{array}{c}0.0034^{* * *} \\
(0.001)\end{array}$ & $\begin{array}{l}0.0006 \\
(0.001)\end{array}$ & $\begin{array}{c}-0.0004 \\
(0.004)\end{array}$ \\
\hline Institutions & $\begin{array}{c}-0.0018 \\
(0.002)\end{array}$ & $\begin{array}{c}-0.0136 \text { * } \\
(0.008)\end{array}$ & $\begin{array}{l}0.0002 \\
(0.002)\end{array}$ & $\begin{array}{c}-0.0017 \\
(0.001)\end{array}$ \\
\hline FDI $\times$ Institutions & $\begin{array}{l}- \\
-\end{array}$ & $\begin{array}{l}- \\
-\end{array}$ & $\begin{array}{c}-0.0227 * \\
(0.014)\end{array}$ & $\begin{array}{l}- \\
-\end{array}$ \\
\hline FDI $\times$ Human capital & - & $\begin{array}{l}- \\
-\end{array}$ & - & $\begin{array}{c}-0.0248 \text { * } \\
(0.015)\end{array}$ \\
\hline Constant & $\begin{array}{c}0.4961^{* * *} \\
(0.092)\end{array}$ & $\begin{array}{c}1.1077 * * \\
(0.446)\end{array}$ & $\begin{array}{c}0.3750 * * * \\
(0.101)\end{array}$ & $\begin{array}{c}0.4117^{* * *} \\
(0.075)\end{array}$ \\
\hline M1 test ( $p$-value) & 0.003 & 0.020 & 0.000 & 0.000 \\
\hline M2 test ( $p$-value) & 0.172 & 0.632 & 0.989 & 0.511 \\
\hline Sargan test ( $p$-value) & 0.261 & 0.918 & 0.043 & 0.011 \\
\hline Hansen test ( $p$-value) & 0.035 & 0.710 & 0.135 & 0.137 \\
\hline Observations & 252 & 252 & 252 & 252 \\
\hline Instrumental variables & 12 & 15 & 24 & 18 \\
\hline
\end{tabular}

Notes: Dependent variable: Gini coefficient, 2012-2018. ${ }^{* * *} p<0.01{ }^{* *} p<0.05 ;{ }^{*} p<0.1$. All the estimations include the standard errors corrected for heteroskedasticity.

The Sargan test or Hansen test is for overidentifying instruments in GMM models, and the M1 and M2 tests are for first- and second-order serial correlation in the residuals, respectively.

In addition to the main results shown, it can also be shown that the qualifications of the trained workers can have an effective reduction in income inequality. Theoretically and practically, an economy with high human capital and good population quality will help reduce income inequality. This result is consistent with previous studies on the effects of human capital on income inequality by Basu and Guariglia (2007); Figini and Görg (2011).

The variable economic growth (lnPGDP) is significant at $1 \%$ with a positive sign. Thus, economic growth in Vietnam leads to an increase in income inequality. This can 
be explained that a country's economic growth can lead to the exacerbation of income inequality if everyone cannot enjoy the outcome of economic development equally.

The estimated coefficient of the urbanization variable has a positive sign and is statistically significant. This means that urbanization has a negative impact on income inequality. This phenomenon can be attributed to the limitations of the recent urbanization process in Vietnam. Urbanization is happening unevenly, mainly in the formation of small cities. When these cities are not effectively managed, the benefits of urbanization may not be realized in increasing productivity and living standards. In addition, rapid and unplanned urbanization of land leads to inappropriately used land funds, rapid decline in agricultural land, affecting employment and income of agricultural workers. On the other hand, besides the impact of the industrialization-modernization process, the proportion of the urban population in the provinces has fluctuated strongly in recent years because of the decisions to re-adjust the administrative boundaries, and this process does not really bring a positive impact to the welfare of the people. It is possible for these reasons that the World Bank (2014) shows that urban poverty is prevalent in small towns and cities in Vietnam, leading to an increase in income inequality.

Another reason that urbanization is positively related to income inequality may be that urban poverty is related to rural-urban migration flows in big cities. Cameron (2012) points out that poor urban households who are rural-urban migrants have fewer assets, live in worse housing conditions in areas with fewer public schools. There is less social connection in the area where they live. The adults in these households have lower levels of education than urban indigenous households. Nguyen Nguyen Viet et al. (2013) found that newcomers to urban areas are more likely to fall into poverty, while those who have been migrating for a long time are often not poor.

The Institutions coefficient in model 3 is negative and statistically significant at $10 \%$. This demonstrates the positive impact of regulations, particularly the government, on reducing income inequality in Vietnam. This implies factors such as: high market entry costs, lack of transparency in the business and business information environment, an unequal competition environment, and business support services satisfying the demand or appropriate labor training policies having a positive effect on reducing inequality in income distribution.

The effects of the variables, including trade openness, inflation, and unemployment are uncertain and need more research to confirm the direction of the impact.

Column 3 in Table 1 shows the estimation results of Model 3-the model that tests the impact of FDI on income inequality under the influence of institutions. The main variable to be considered in Model (3) is the interaction variable between FDI and institutionsrepresented by the variable FDI $\times$ Institutions. As a result, the coefficient of the interaction variable between FDI and institutions (FDI $\times$ Institutions) is negative and is statistically significant at $10 \%$. Estimated results suggest that FDI will have a reduction in income inequality in provinces with a better quality of economic governance and administrative reform efforts. In other words, under the influence of regulation quality, FDI will have the effect of narrowing income inequality in Vietnam.

Column 4 in Table 1 shows the results of Model 4 -the model testing the impact of FDI on income inequality through human capital. In Model (5), the interaction variable FDI $\times$ Human Capital is negative and significant at $10 \%$. The results shows FDI's positive affects to reduce income inequality under the influence of human capital/education level. This can be explained that when localities improve the quality of human capital, focus on developing skills and qualifications it not only attracts FDI but also thereby reduces the income inequality in the local area.

\section{Conclusions and Policy Implications}

The main purpose of this study is to investigate empirically the direct impact of FDI on income inequality and also the impact of FDI on income inequality with the moderating effect of provinces' level of education and institutions. Based on theoretical 
discussions and empirical experiences, a panel data set containing Vietnam's 63 provinces over the period 2012-2018 is used under a GMM system estimator. The study provides the following main findings. First, the study finds that while FDI has directly contributed to increasing income inequality, FDI has also contributed to reducing income inequality with the moderating effect of provinces' level of education and institutions. Second, a nonlinearity relationship between FDI and income inequality is also confirmed, which suggests that the expansion of FDI leads to an increase in income inequality, but at a decreasing rate over time. Third, the negative effect of economic development on income inequality is validated, which implies that income inequality in Vietnam will be gradually increased as Vietnam's economy continues to grow and per capita income keeps rising. Fourth, urbanization has contributed to increasing income inequality in Vietnam. This issue may be due to the unbalanced urbanization which leads to the formation of small towns and the rapid decline of agricultural land in Vietnam. These changes finally affect employment and labor income. Fifth, the development of human capital has a significant effect to reducing income inequality, which implies that improving the overall quality of human resources will benefit everyone and improve income equality. Finally, the improvement of economic governance at the provincial level will lead to reducing income inequality in Vietnam.

The paper makes two major contributions to the literature. First, the paper adopts the system-GMM estimator to deal with the endogeneity issues in estimating the impact of FDI on income inequality, producing more consistent estimates. Second, the paper investigates not only the direct impact of FDI on income inequality but also the impact of FDI on income inequality with the moderating effect of provinces' level of education and economic governance, adding new empirical evidence to the sparse literature on the impact of FDI on income inequality in Vietnam.

The study has some policy implications. There are different types of policies that affect the interface between FDI and income inequality: host country policies (human resource development and infrastructure, industrial policy, incentives and other FDI policy, etc.); home country (outward investment missions, investment guarantees, bilateral investment funds) and international policies (multilateral, regional and bilateral investment treaties). For the host country policies, there are some useful policies to reduce income inequality. First, as the study finds that FDI not only contributes to increasing income inequality but also contributes to reducing income inequality with the moderating effect of provinces' level of economic governance, therefore, Vietnam's policies should focus on improving the quality of economic governance and the administrative reform efforts of the government of the provinces and cities. Second, Vietnam has not been successful in providing good quality and appropriate education and training. Aiming for good quality human resource development at the lower end of the labor market $t$ would also have a positive impact on the way in which FDI affects inequality. Therefore, policies should focus on increasing investment in public education and improving human capital, for instance supplying a good educational basis (at least secondary education) and an appropriate technical education, which not only can reduce income inequality but also can attract more FDI inflows. Besides, the government can encourage training in MNEs and other firms. When firms pay for training, the employees do not capture all the benefits from training; in reality, firms capture some by raising productivity more than wages. Third, the negative impact of urbanization on income inequality implies that poor migrants in cities need to receive more attention, especially in the early stages of migration. Finally, with a developing country like Vietnam, ensuring social equity in general, minimizing income inequality in particular, plays an important role in social stability towards sustainable development. Therefore, it is believed that Vietnam's policies to attract and use FDI should be linked with social security policies, reducing income inequality.

Author Contributions: Conceptualization, methodology, supervision, Q.H.L.; writing-original draft preparation, writing — review and editing, Q.A.D.; data, supervision, H.C.P.; writing-review and editing, T.D.N. All authors have read and agreed to the published version of the manuscript. 
Funding: This research is funded by the National Economics University, Hanoi, Vietnam.

Data Availability Statement: The data presented in this study are available on request from the corresponding author.

Conflicts of Interest: The authors declare no conflict of interest.

\section{References}

Aghion, Philippe, and Peter Howitt. 2009. The Economics of Growth. Cambridge: MIT Press.

Aitken, Brian J., and Ann E. Harrison. 1999. Do domestic firms benefit from direct foreign investment? Evidence from Venezuela. American Economic Review 89: 605-18. [CrossRef]

Alderson, Arthur S., and Francois Nielsen. 1999. Income Inequality, Development, and Dependence: A Reconsideration. American Sociological Review 64: 606-31. [CrossRef]

Arellano, Manuel, and Stephen Bond. 1991. Some Tests of Specification for Panel Data: Monte Carlo Evidence and an Application to Employment Equations. Review of Economic Studies 58: 277-97. [CrossRef]

Barro, Robert J. 2000. Inequality and Growth in a Panel of Countries. Journal of Economic Growth 5: 5-32. [CrossRef]

Basu, Parantap, and Alessandra Guariglia. 2007. Foreign Direct Investment, Inequality, and Growth. Journal of Macroeconomics 29: 824-39. [CrossRef]

Beer, Linda, and Terry Boswell. 2002. The Resilience of Dependency Effects in Explaining Income Inequality in the Global Economy: A Cross National Analysis, 1975-1995'. Journal of World-Systems Research 8: 30-59. [CrossRef]

Bellak, Christian. 2015. Economic Impact of Investment Agreements. Vienna: Department of Economics Working Paper Series, WU Vienna University of Economics and Business.

Bhandari, Bornali. 2007. Effect of Inward Foreign Direct Investment on Income Inequality in Transition Countries. Journal of Economic Integration 22: 888-928. [CrossRef]

Blonigen, Bruce, and Matthew Slaughter. 2001. Foreign-affiliate Activity and US Skill Upgrading. Review of Economics and Statistics 83: 362-76. [CrossRef]

Bodea, Cristina, and Fangjin Ye. 2017. Bilateral Investment Treaties (BITs): The Global Investment Regime and Human Rights. British Journal of Political Science. [CrossRef]

Cameron, Stuart. 2012. Education, Urban Poverty and Migration: Evidence from Bangladesh and Vietnam. Working Paper 2012-2015. Florence: UNICEF Office of Research.

Cantwell, John, John H. Dunning, and Sarianna M. Lundan. 2010. An evolutionary approach to understanding international business activity: The co-evolution of MNEs and the institutional environment. Journal of International Business Studies 41: 567-86. [CrossRef]

Chaisse, Julien, and Christian Bellak. 2015. Navigating the Expanding Universe of Investment Treaties-Creation and Use of Critical Index. Journal of International Economic Law, 79-115. [CrossRef]

Chintrakarn, Pandej, Dierk Herzer, and Peter Nunnenkamp. 2012. Fdi and income inequality: Evidence from a panel of U.S. states. Economic Inquiry 50: 788-801. [CrossRef]

Choi, Changkyu. 2006. Does foreign direct investment affect domestic income inequality? Applied Economics Letters 13: 811-14. [CrossRef]

Cingano, Federico. 2014. Trends in Income Inequality and its Impact on Economic Growth. OECD Social, Employment and Migration Working Papers, No. 163. Paris: OECD Publishing.

Dix-Carneiro, Rafael. 2014. Trade liberalization and labor market dynamics. Econometrica 82: 825-85.

Faustino, Horácio, and Carim Vali. 2011. The Effects of Globalisation on OECD Income Inequality: A Static and Dynamic Analysis. Working Papers Department of Economics 2011/12. Lisbon: ISEG-Lisbon School of Economics and Management, Department of Economics, Universidade de Lisboa.

Feenstra, Robert C., and Gorden H. Hanson. 1997. Foreign direct investment and relative wages: Evidence from Mexico's maquiladoras. Journal of International Economics 42: 371-93. [CrossRef]

Figini, Paolo, and Holger Görg. 2011. Does Foreign Direct Investment Affect Wage Inequality? An Empirical Investigation. The World Economy 34: 1455-75. [CrossRef]

Franco, Chiara, and Elisa Gerussi. 2013. Trade, foreign direct investments (FDI) and income inequality: Empirical evidence from transition countries. Journal of International Trade and Economic Development 22: 1131-60. [CrossRef]

Girma, Sourafel, and Holger Görg. 2007. Evaluating the Foreign Ownership Wage Premium using a Difference-in-differences Matching Approach. Journal of International Economics 72: 97-112. [CrossRef]

Goldberg, Linda S., and Michael W. Klein. 2005. International Trade and Factor Mobility: An Empirical Investigation. SSRN Electronic Journal 47: 321-35. [CrossRef]

Gopinath, Munisamy, and Weiyan Chen. 2010. Foreign direct investment and wages: A cross-country analysis Foreign direct investment and wages: A cross-country analysis. Journal of International Trade and Economic Development 8199: 285-309. [CrossRef]

Heckscher, Eli F., Bertil Ohlin, Harry Flam, and M. June Flanders. 1991. Heckscher-Ohlin Trade Theory. Cambridge: MIT Press. 
Hemmer, Hans-Rimbert, Ralf Krüger, and Jennifer Seith. 2005. Foreign Direct Investment and Income Inequality Revisited. No. 32, Discussion Papers in Development Economics from Justus Liebig University Giessen, Institute for Development Economics. Giessen: JustusLiebig-University Giessen.

Herzer, Dierk, and Peter Nunnenkamp. 2011. FDI and income inequality: Evidence from Europe. No 1675, Kiel Working Papers. Kiel: Kiel Institute for the World Economy.

Hue, Nguyen Thi. 2016. Research on Factors Influencing the Rich-Poor Gap in Vietnam. Ph.D. Thesis, National Economics University, Hanoi, Vietnam.

Hung, Nguyen Thi Thai. 2019. Assessment of the Impact of Foreign Direct Investment on Income Inequality in Vietnam in the Period 2007-2017. Project 2019. Hanoi: Banking Academy.

Huyen, Thanh Nguyen. 2012. The Impact of International Integration on Rural-Urban Income Inequality in Vietnam. Ph.D. Thesis, National Economics University, Hanoi, Vietnam.

Javorcik, Beata Smarzynska. 2004. Does foreign direct investment increase the productivity of domestic firms? in search of spillovers through backward linkages. American Economic Review 94: 605-27. [CrossRef]

Jensen, Nathan M., and Guillermo Rosas. 2007. Foreign direct investment and income inequality in Mexico, 1990-2000. International Organization 61: 467-87. [CrossRef]

Jin, Furong. 2009. Foreign Direct Investment and Income inequality in China. Seoul Journal of Economics 22: 311-39.

Kugler, Maurice. 2006. Spillovers from foreign direct investment: Within or between industries? Journal of Development Economics 80: 444-77. [CrossRef]

Le, Quoc Hoi. 2019. The impact of Credit on Income Inequality in Vietnam: An empirical analysis. Journal of Economics and Development 21: $5-18$.

Lipsey, Robert E., and Fredrik Sjöholm. 2004. Foreign direct investment, education and wages in Indonesian manufacturing. Journal of Development Economics 73: 415-22. [CrossRef]

Milanovic, Branko. 2002. Determinants of Cross-Country Income Inequality: An "Augmented" Kuznets Hypothesis. In Equality. Participation. Transition. Edited by V. Franicevic and M. Uvalic. London: MacMillan Press Ltd., pp. 48-79.

Mugeni, Sandrine. 2015. Foreign Investment, Democracy and Income Inequality: Empirical Evidence. pp. 1-46. Major paper Represented to the Department of Economics of the University of Ottowa in Partial Fulfilment of the Requirements of the M.A Degree. Available online: https:/ /ruor.uottawa.ca/bitstream/10393/32373/1/Mugeni_Sandrine_2015_researchpaper.pdf (accessed on 20 October 2020).

Nam, Hoai Trinh. 2016. The effect of foreign direct investment on income inequality in Vietnam. International Journal of Economics, Commerce and Management IV: 158-73.

Nga, Quynh Duong, and Cao Minh Tri. 2017. The impact of foreign direct investment on income inequality. Journal of Industry and Trade, 417-429.

Nguyen Viet, Cuong, Linh Vu Hoang, and Thang Nguyen. 2013. Urban poverty in Vietnam: Determinants and policy implications. International Journal of Development Issues 12: 110-39. [CrossRef]

Peng, Mike W., Denis Y. L. Wang, and Yi Jiang. 2008. An institution-based view of international business strategy: A focus on emerging economies. Journal of International Business Studies 39: 920-36. [CrossRef]

Reuveny, Rafael, and Quan Li. 2003. Economic openness, democracy, and income inequality: An empirical analysis. Comparative Political Studies 36: 575-601. [CrossRef]

Sylwester, Kevin. 2005. Foreign direct investment, growth and income inequality in less developed countries. International Review of Applied Economics 19: 289-300. [CrossRef]

Taylor, Karl, and Nigel Driffield. 2005. Wage Inequality and the Role of Multinationals: Evidence from UK Panel Data. Labour Economics 12: 223-49. [CrossRef]

Te Velde, Dirk. 2003. Foreign Direct Investment and Income Inequality in Latin America Experiences and Policy Implications. London: Overseas Development Institute.

Te Velde, Dirk W., and Theodora Xenogiani. 2007. Foreign Direct Investment and International Skill Inequality. Oxford Development Studies 35: 83-104. [CrossRef]

Tsai, Pan-Long. 1995. Foreign direct investment and income inequality: Further evidence. World Development 23: 469-83.

Vinh, Cao, Lu Trang, and Nguyen Hoa. 2014. The Impact of Heterogeneous Bilateral Investment Treaties (BIT) on Foreign Direct Investment (FDI) Inflows to Vietnam. Papers 916. Hallerstrasse: World Trade Institute, University of Bern.

World Bank. 2014. Well Begun but Not Yet Done: Progress and Emerging Challenges for Poverty Reduction in Vietnam. Washington, DC: World Bank Group. 